\title{
The effect of crutches, an orthosis TheraTogs, and no walking aids on the recovery of gait in a patient with delayed healing post hip fracture: A case report
}

Citation for published version (APA):

Maguire, C., Sieben, J. M., Scheidhauer, H., Romkes, J., Suica, Z., \& de Bie, R. A. (2016). The effect of crutches, an orthosis TheraTogs, and no walking aids on the recovery of gait in a patient with delayed healing post hip fracture: A case report. Physiotherapy Theory and Practice, 32(1), 69-81.

https://doi.org/10.3109/09593985.2015.1075640

Document status and date:

Published: 02/01/2016

DOI:

10.3109/09593985.2015.1075640

Document Version:

Publisher's PDF, also known as Version of record

Document license:

Taverne

Please check the document version of this publication:

- A submitted manuscript is the version of the article upon submission and before peer-review. There can be important differences between the submitted version and the official published version of record.

People interested in the research are advised to contact the author for the final version of the publication, or visit the DOI to the publisher's website.

- The final author version and the galley proof are versions of the publication after peer review.

- The final published version features the final layout of the paper including the volume, issue and page numbers.

Link to publication

\footnotetext{
General rights rights.

- You may freely distribute the URL identifying the publication in the public portal. please follow below link for the End User Agreement:

www.umlib.nl/taverne-license

Take down policy

If you believe that this document breaches copyright please contact us at:

repository@maastrichtuniversity.nl

providing details and we will investigate your claim.
}

Copyright and moral rights for the publications made accessible in the public portal are retained by the authors and/or other copyright owners and it is a condition of accessing publications that users recognise and abide by the legal requirements associated with these

- Users may download and print one copy of any publication from the public portal for the purpose of private study or research.

- You may not further distribute the material or use it for any profit-making activity or commercial gain

If the publication is distributed under the terms of Article $25 \mathrm{fa}$ of the Dutch Copyright Act, indicated by the "Taverne" license above, 


\section{The effect of crutches, an orthosis TheraTogs, and no walking aids on the recovery of gait in a patient with delayed healing post hip fracture: A case report}

Clare Maguire, Judith M. Sieben, Heike Scheidhauer, Jacqueline Romkes, Zorica Suica \& Robert A. de Bie

To cite this article: Clare Maguire, Judith M. Sieben, Heike Scheidhauer, Jacqueline Romkes, Zorica Suica \& Robert A. de Bie (2016) The effect of crutches, an orthosis TheraTogs, and no walking aids on the recovery of gait in a patient with delayed healing post hip fracture: A case report, Physiotherapy Theory and Practice, 32:1, 69-81, DOI: 10.3109/09593985.2015.1075640

To link to this article: https://doi.org/10.3109/09593985.2015.1075640

Published online: 12 Jan 2016.

Џlll Article views: 410

View Crossmark data $\longleftarrow$
Submit your article to this journal $\sqsubset$ 


\title{
The effect of crutches, an orthosis TheraTogs, and no walking aids on the recovery of gait in a patient with delayed healing post hip fracture: A case report
}

\author{
Clare Maguire, MPTSca,b, Judith M. Sieben, $\mathrm{PhD}^{c}$, Heike Scheidhauer, Dr.paed ${ }^{\mathrm{a}}$, Jacqueline Romkes, $\mathrm{PhD}^{\mathrm{d}}$,
} Zorica Suica, MSc ${ }^{\mathrm{a}, \mathrm{e}}$, and Robert A. de Bie, MSc, RPT, PhD

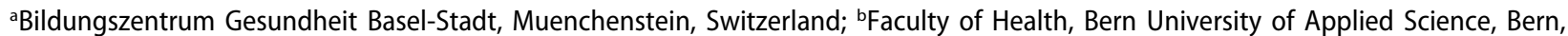

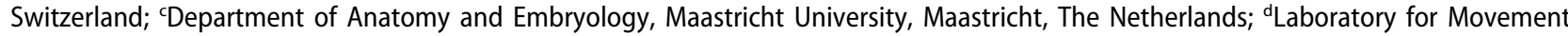

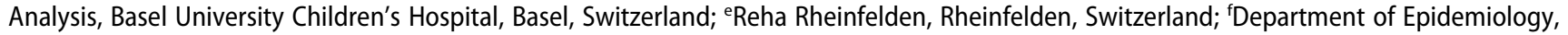
Maastricht University, Maastricht, The Netherlands
\end{abstract}

\begin{abstract}
Accelerated rehabilitation following hip fracture and joint replacement, including early unrestricted weight-bearing and muscle strengthening, has gained importance in hastening functional recovery and hospital discharge. The influence of walking aids on these parameters is sparsely investigated. In this case report, we document the effect of walking with crutches; an orthotic garment and strapping system, TheraTogs; and no walking aids over 3-4-week periods on walking speed, trunk sway, and muscle activity measured with electromyography (EMG). The patient was a 49-year-old female showing delayed healing following a conservatively treated avulsion fracture of the greater trochanter 12 weeks previously with a 14-year history of total hip arthroplasty. EMG analysis showed muscle activity increased with TheraTogs and decreased with crutches compared with walking with no aids. Walking speed improved at a faster rate in the TheraTogs phase than in the crutches phase and reduced in no-walking-aids phase. Mean speed (SD) for each phase was: crutches $1.11(0.08) \mathrm{m} / \mathrm{s}$, TheraTogs $1.35(0.11) \mathrm{m} / \mathrm{s}$, and no-aids 1.19 $(0.14) \mathrm{m} / \mathrm{s}$. Trunk sway increased in the crutch and no-aids phases, and became more stable in the TheraTogs phase. In this patient, function and recovery rate of all measured parameters increased more in the TheraTogs phase than the crutches or no-aids phase. This may be because muscle activity was facilitated enabling active support of recovering structures.
\end{abstract}

ARTICLE HISTORY

Received 1 August 2014

Revised 19 March 2015

Accepted 3 April 2015

\section{KEYWORDS}

Accelerated rehabilitation; hip fracture; muscle strength; unrestricted weight-bearing; walking aids

\section{Introduction}

Accelerated rehabilitation for patients following hip fracture or total hip replacement (THR) has become established over the last decade to hasten functional recovery and shorten hospital stay ( $\mathrm{Hol}$ et al, 2010; Hung, Egol, Zuckerman, and Siu, 2012; Robbins et al, 2014; Tayrose et al, 2013). Early or immediate unrestricted weight-bearing is an important aspect of these programs.

Additionally, the importance of regaining hip muscle strength to improve patient outcomes and reduce healthcare costs for patients following joint replacement and hip fracture has been demonstrated (Borrelli et al, 2006; Piva et al, 2011; Zhao, Chen, Lee, and $\mathrm{Wu}, 2013$ ).

Deficiency of the hip abductor mechanism is however a common complication following THR with a reported incidence of up to 20\% (Garcia, Picado, and Nogueira-Barbos, 2010; Masonis and Bourne, 2002). This may be preexisting and found during surgery or it may occur during surgery as a result of damage to the superior gluteal nerve or due to the detachment of the abductor muscles from the greater trochanter (Odak and Ivory, 2013). Fracture of the femur is also a common complication with 5\% involving the greater trochanter (Pritchett, 2001). Recovery may occur spontaneously or surgery may be necessary if conservative treatment fails. For these patients, unrestricted weight-bearing and muscle strengthening can be delayed.

As the choice of walking aid in orthopedic rehabilitation clearly influences weight-bearing status and has a significant impact on muscle activity (Maguire, Sieben, Frank, and Romkes, 2010; Neumann, 1998; Sonntag et al, 2000), the prescription of appropriate assistive devices to optimize recovery is important.

Canes and crutches enable partial and non-weight-bearing gait thus unloading joints and potentially reducing pain when walking. However, they have also been shown, in cross-sectional studies, to reduce muscle activity, gait

CONTACT Clare Maguire, MPTSc clare.maguire@bzgbs.ch, clare.maguire@bfh.ch $\Theta$ Physiotherapy Department, Bildungszentrum Gesundheit Basel- 
speed, and cadence (Maguire, Sieben, Frank, and Romkes, 2010; Neumann, 1998; Sonntag et al, 2000). Crutches cause abnormal activation patterns in hip abductor muscles following hip arthroplasty (Sonntag et al, 2000), and restricted weight-bearing through assistive devices, which use the upper limbs, significantly increases energy expenditure (Westerman, Hull, Hendry, and Cooper, 2008).

As many patients are unable to walk without some form of walking aid immediately post-operatively, assistive devices which support the affected structures without reducing muscle activity or requiring the use of the upper limbs could be more beneficial than handheld walking aids. This may be particularly relevant for patients with a defective hip abductor mechanism.

An elasticized orthotic garment and strapping system named TheraTogs ${ }^{\mathrm{TM}}$ (Telluride, CO, USA), which does not require use of the arms, has shown promising results regarding muscle activity when tested with patients following stroke (Maguire, Sieben, Frank, and Romkes, 2010). This study showed that hip abductor activity increased by $16.5 \%$ when walking with the orthotic garment compared with walking without walking aids. Studies have also indicated that TheraTogs facilitates improvements in bone alignment and kinematic gait parameters in children with neurological conditions (Abd El-Kafy, 2014; Richards, Morcos, Rethlefsen, and Ryan, 2012). To our knowledge, this system has not been tested in orthopedic patients.

In this clinically driven case report, we outline the effects of crutches, the orthosis TheraTogs, and no walking aids during the gait rehabilitation of a 49 -year-old patient with delayed healing of a conservatively treated avulsion fracture of the greater trochanter having undergone THR 14 years previously. Written consent was obtained from the patient.

\section{Case description}

The patient was a 49-year-old female $(160 \mathrm{~cm}, 50 \mathrm{~kg})$ who had undergone a left total hip arthroplasty 14 years previously, suffering an incomplete lesion of the lumbar plexus during surgery resulting in residual muscle weakness. Subsequent replacement of the acetabulum was necessary twice, 7 and then 8 years after original surgery due to initial incorrect positioning of the acetabulum component. Twelve weeks before the reported course of treatment, the patient had stumbled causing an avulsion fracture of the greater trochanter, leaving the prosthetic implant at this level without bony covering and having direct contact with overlying soft tissues (Figure 1). Surgical repair was not recommended at this stage as the original incorrect positioning of the acetabulum and repeated surgical corrections

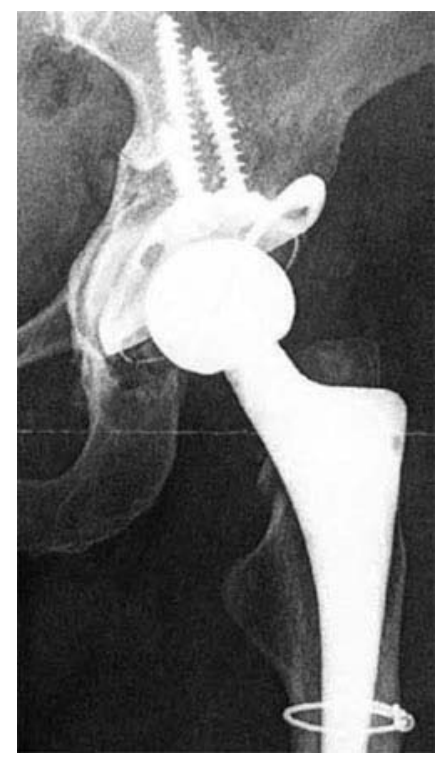

Figure 1. Plain radiograph (AP view) taken on initial presentation, showing an avulsion fracture of the greater trochanter, leaving the shoulder of the prosthesis in direct contact with soft tissues (circled).

had resulted in poor bone quality. The fracture was treated conservatively and the patient was nonweight-bearing for 5 weeks after which she could progress to partial then to full weight-bearing, as the pain allowed.

Twelve weeks post-fracture, the patient continued to walk with elbow crutches and attempted to reduce crutch use. Normal progression to full weight-bearing without assistive devices was delayed due to high levels of pain. Physiotherapy treatment consisted of advice and exercise prescription when in hospital and nothing further since discharge. The patient had now requested assistance with the reduction of crutch use and the progression to full weight-bearing.

Before fracture the patient walked independently without aids for $2-3 \mathrm{~km}$, at which point she would rest. Stair climbing was possible using a bannister. A slight Trendelenburg was visible after walking long distances, indicating underlying hip abductor weakness. The patient had no other medical or surgical complaints.

\section{Clinical examination}

\section{Social history}

The patient worked as a teacher. She had pain standing for long periods in the classroom and was currently working more with office and administrative tasks. She was able to drive to and from work. She lived with her husband in a house with stairs. Her active hobbies were 
cycling (usually tandem), e-biking (a bicycle with an integrated electric motor), and diving.

\section{Pain}

A deep burning pain becoming sharp and intense began over the lateral aspect of the left hip (site of greater trochanter fracture) $\left(\mathrm{P}_{1}\right.$ on body chart, Figure 2a) after 15-20 min walking on flat ground and partial weight-bearing with two crutches. This radiated to the medial aspect of the knee joint if the patient continued to walk $\left(\mathrm{P}_{2}\right)$. These pains varied between 3 and 8 on the Visual Analogue Scale (VAS). Pain began at 3 on VAS and became quickly worse if the patient attempted to walk through the pain or to reduce weight-bearing on the crutches. Pain was also present in the left buttock when attempting to reduce weight-bearing on the crutches $\left(\mathrm{P}_{3}\right)$ (VAS 4-5) (Figure 2b). This increased significantly during stair climbing or after sitting for 30-60 min. Generalized groin pain $\left(\mathrm{P}_{4}\right)$ (VAS 3-4) was not present in the morning but increased through the day. All pain was reduced after 1-3 h of complete rest in lying with the hip in extension and slight abduction.

\section{Medication}

Paracetamol (325 mg)/Tramadol $(37.5 \mathrm{mg}$ ) was taken 2-4 times daily as needed for pain.

(a)

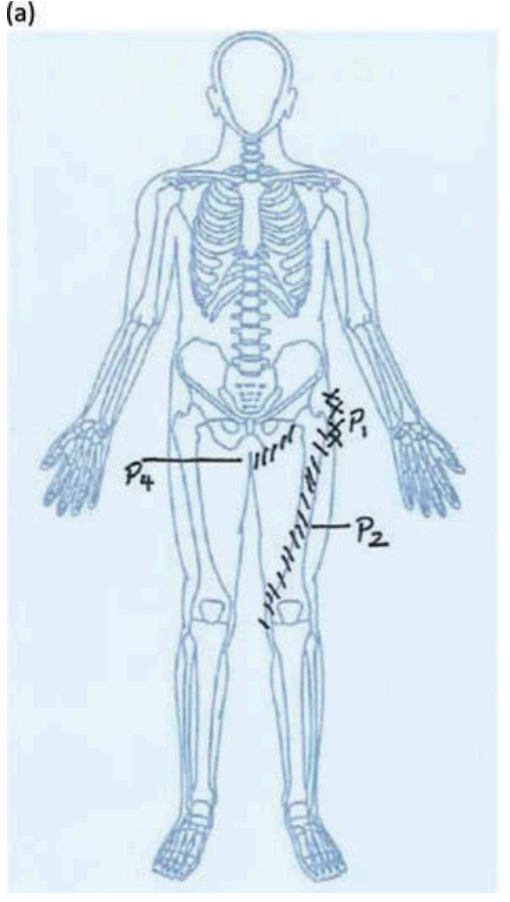

\section{Observation}

\section{Gait}

The patient had a Trendelenberg gait pattern when walking without crutches.

\section{Standing}

Weight-bearing was predominantly on the right leg with atrophy of left gluteus medius and hypertrophy of left tensor fascia lata (TFL). Atrophy of left-sided quadriceps, hamstrings, and gastrocnemius was also noted (Table 1).

\section{Palpation}

Generalized tenderness was noted over the lateral aspect of the left hip with over-activity and hypertrophy of left TFL.

\section{Reflexes}

The patellar tendon reflex was reduced on the left and normal on the right. The Achilles tendon reflex was absent on the left and normal on the right.

\section{Problem analysis and clinical hypotheses}

The dislocated greater trochanter (displaced dorsally and cranially as seen on $\mathrm{x}$-ray) left the hip prosthesis without bony covering. This caused the shoulder of the prosthesis to irritate overlying soft tissues during all hip movements, but particularly during joint loading

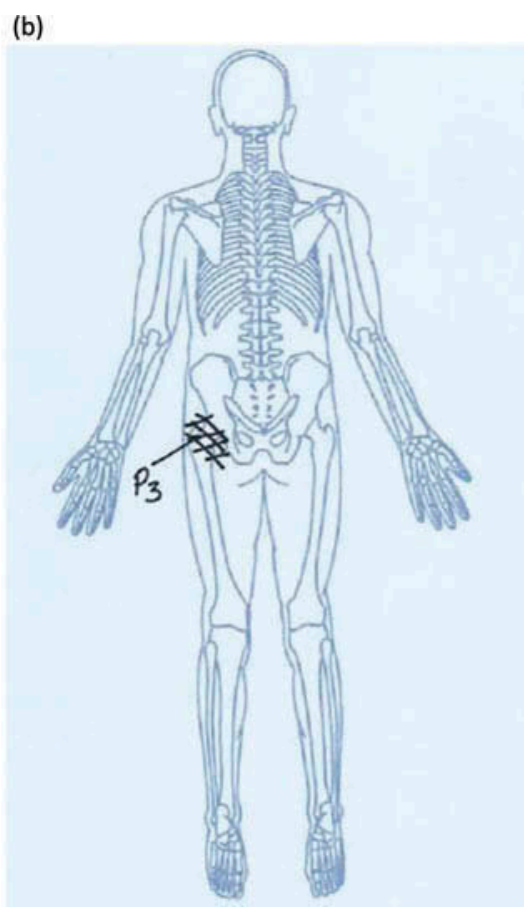

Figure 2. (a) Body chart showing areas of pain $P_{1}, P_{2}$, and $P_{4}$. (b) Body chart showing areas of pain $P_{3}$. 
Table 1. Active and passive range of movement in the hip, knee, and ankle joints of the left leg.

\begin{tabular}{|c|c|c|c|c|c|c|}
\hline & \multicolumn{6}{|c|}{ Hip joint range of movement (ROM) and muscle strength } \\
\hline & Flexion & Extension & Abduction & Adduction & Internal rotation & External rotation \\
\hline Active ROM & $80^{\circ}$ & $0^{\circ}$ & $30^{\circ}$ & $0^{\circ}$ & $5^{\circ}$ & $20^{\circ}$ \\
\hline Left & Limited by pain & Limited by pain & Limited by pain & Limited by pain & Limited by pain & Limited by pain \\
\hline Right & Full range & Full range & Full range & Full range & Full range & Full range \\
\hline Passive ROM & $100^{\circ}$ & $0^{\circ}$ & $40^{\circ}$ & $10^{\circ}$ & $10^{\circ}$ & $30^{\circ}$ \\
\hline Left & Limited by pain & Limited by pain & Limited by pain & Limited by pain & Limited by pain & Limited by pain \\
\hline Right & Full range & Full range & Full range & Full range & Full range & Full range \\
\hline \multicolumn{7}{|l|}{ Strength: Manual Muscle Test } \\
\hline Left & 4 & 4 & $2-3$ & 4 & 3 & 4 \\
\hline \multirow[t]{3}{*}{ Right } & 5 & 5 & 5 & 5 & 5 & 5 \\
\hline & \multicolumn{6}{|c|}{ Range of movement and strength in lower limbs } \\
\hline & Knee flexion & Knee extension & Ankle dorsiflexion & Ankle plantarflexion & Ankle inversion & Ankle eversion \\
\hline Active ROM Left & Full range & Full range & $80^{\circ}$ & Full range & Full range & Full range \\
\hline Right & Full range & Full range & Full range & Full range & Full range & Full range \\
\hline Passive ROM Left & Full range & Full range & Full range & Full range & Full range & Full range \\
\hline Right & Full range & Full range & Full range & Full range & Full range & Full range \\
\hline \multicolumn{7}{|l|}{ Strength: Manual Muscle Test } \\
\hline Left & 4 & 4 & 3 & 4 & 4 & 3 \\
\hline Right & 5 & 5 & 5 & 5 & 5 & 5 \\
\hline
\end{tabular}

Note. Muscle strength of hip and lower limb muscle groups tested with the Manual Muscle Test.

Table 2. Problem list based on the International Classification of Functioning (ICF).

\begin{tabular}{|c|c|c|}
\hline $\begin{array}{l}\text { Body functions and } \\
\text { structures }\end{array}$ & Activities & Participation \\
\hline $\begin{array}{l}\text { Gradually increasing } \\
\text { pain after walking } \\
15-20 \text { min with two } \\
\text { crutches }\end{array}$ & $\begin{array}{l}\text { Patient unable to } \\
\text { progress to fully } \\
\text { weight-bearing and } \\
\text { independent walking } \\
\text { without crutches }\end{array}$ & $\begin{array}{l}\text { Patient's work } \\
\text { environment } \\
\text { limited to } \\
\text { sedentary tasks }\end{array}$ \\
\hline $\begin{array}{l}\text { Pain when stair } \\
\text { climbing and after } \\
\text { sitting for } 30 \mathrm{~min}\end{array}$ & $\begin{array}{l}\text { Patient unable to climb } \\
\text { stairs }\end{array}$ & $\begin{array}{l}\text { Unable to participate } \\
\text { in active hobbies, } \\
\text { for example, diving } \\
\text { and cycling }\end{array}$ \\
\hline $\begin{array}{l}\text { Generalized weakness } \\
\text { in the hip and } \\
\text { leg muscles, } \\
\text { particularly hip } \\
\text { abductors (gluteus } \\
\text { medius and } \\
\text { minimus) causing } \\
\text { marked } \\
\text { Trendelenburg gait } \\
\text { pattern and } \\
\text { increased trunk }\end{array}$ & & $\begin{array}{l}\text { Limited in some } \\
\text { household tasks } \\
\text { and shopping }\end{array}$ \\
\hline $\begin{array}{l}\text { sway } \\
\text { Reduced active and } \\
\text { passive hip ROM } \\
\text { limited by pain }\end{array}$ & & \\
\hline
\end{tabular}

causing increased inflammation and pain. The patient was able to walk short distances with crutches as the joint was partially unloaded. Walking without aids increased loading and therefore soft tissue irritation and pain (Table 2).

As the greater trochanter is the insertion for gluteus medius and gluteus minimus, the displacement of this fragment also led to a defective hip abductor mechanism leading to compensation and increased activity of TFL. Weakness in the other muscle groups was a long-standing problem caused by the incomplete lesion of the lumbar plexus during surgery 14 years previously. This was also the cause of the reduced spinal reflexes. No further deficits in the lumbar region which may have affected gait function (e.g., core stability or mobility) were found.

\section{Physiotherapy diagnosis and treatment plan}

As pain was caused by the ongoing irritation and inflammation of tissues overlying the exposed prosthesis when walking, it was considered that short-term symptomatic treatment of pain with physiotherapy interventions would not be effective. In order to enable pain-free or pain-reduced walking without aids, treatment should attempt to increase support around the hip joint and exposed prosthesis during weight-bearing. This could be achieved primarily through strengthening of all hip muscle groups including the remaining hip abductor musculature (TFL and possibly muscular contractile elements from gluteus maximus which can fuse with the gluteal aponeurosis) (Netter, 2014). Crutch use should be gradually reduced as muscle strength increases. A muscle strengthening program combined with a gradual reduction of crutch use was prescribed.

\section{Prognostic indicators}

Compensatory strategies are developed by a large proportion of patients in the presence of defective hip abductor mechanisms (Howell, Biggs, and Bourne, 2001; Odak and Ivory, 2013; Williams and Cohen, 2009). The physical requirements necessary to develop these strategies have not been reported (as far as the authors are aware). Positive predictive indicators in this patient which may have supported this ability were considered to be age (49 years), low BMI, moderate levels of cardiovascular fitness, and high motivation. 
Table 3. Aims of treatment related to ICF problem list (formulated with patient).

\begin{tabular}{|c|c|c|}
\hline $\begin{array}{l}\text { Short-term treatment } \\
\text { aims ( } 2-6 \text { weeks) }\end{array}$ & $\begin{array}{l}\text { Long-term treatment } \\
\text { aims (6-12 weeks) }\end{array}$ & $\begin{array}{l}\text { Long-term treatment } \\
\text { aims (6-12 weeks) }\end{array}$ \\
\hline $\begin{array}{l}\text { Body functions and } \\
\text { structures }\end{array}$ & Activities & Participation \\
\hline $\begin{array}{l}\text { Strengthening of hip } \\
\text { and lower extremity } \\
\text { muscle groups, } \\
\text { particularly hip } \\
\text { abductor and } \\
\text { extensor groups }\end{array}$ & $\begin{array}{l}\text { Improved gait pattern } \\
\text { with reduced } \\
\text { Trendelenburg and } \\
\text { trunk sway }\end{array}$ & $\begin{array}{l}\text { Patient able to stand, } \\
\text { walk, and climb } \\
\text { stairs as necessary } \\
\text { at work and during } \\
\text { household tasks } \\
\text { without walking } \\
\text { aids }\end{array}$ \\
\hline $\begin{array}{l}\text { Graded and supervised } \\
\text { reduction of crutch } \\
\text { walking (increasing } \\
10 \text { min pain-free per } \\
\text { week) }\end{array}$ & $\begin{array}{l}\text { Pain-free, independent } \\
\text { walking without } \\
\text { walking aids for } 2-3 \\
\text { km (approximately } 1 \mathrm{~h} \text { ) }\end{array}$ & $\begin{array}{l}\text { Able to participate in } \\
\text { more active } \\
\text { hobbies; for } \\
\text { example, cycling }\end{array}$ \\
\hline $\begin{array}{c}\text { Increased active and } \\
\text { passive hip ROM }\end{array}$ & $\begin{array}{l}\text { Ability to climb stairs } \\
\text { using a bannister, } \\
\text { pain-free }\end{array}$ & \\
\hline
\end{tabular}

However, it was clear that the challenges posed by the exposed prosthesis could not be reduced with conservative treatment. Significant increases in muscle strength in surrounding muscle groups would be necessary to adequately support the hip joint and exposed soft tissues. The large changes required in muscle strength to enable independent gait and the incomplete lesion of the lumbar plexus were considered negative prognostic indicators.

As the patient was very eager to attempt to achieve her goals without surgery, and because surgery was not recommended at this stage due to weakening of the bone from previous operations, conservative management as outlined was indicated (Table 3).

\section{Outcome measures}

Outcome measurements consisted of:

(1) Gait speed measured twice weekly: Changes in gait speed in a female population following hip fracture have been shown to indicate meaningful functional change (Alley et al, 2011).

(2) Dynamic hip muscle function measured twice weekly evaluated through trunk sway using the SwayStar instrumentation: This method was chosen because direct measurement of muscle strength using the manual muscle test was painful for hip abductor muscles. Trunk sway has been used in hip fracture and normal subjects to assess abductor muscle function (Archdeacon et al, 2008; Klemetti et al, 2014).

(3) Patient report of distance and time walked daily without crutches with minimal or no pain.
To measure gait speed and trunk sway the patient was instructed to stand with feet level at the starting line of an $8 \mathrm{~m}$ marked level track and when given the cue to start to walk at a comfortable speed and to stop at the end. Time to complete was measured using the SwayStar instrumentation, and gait speed was calculated.

The SwayStar balance system (Balance International Innovations $\mathrm{GmbH}$, Iseltwald, Switzerland) consists of two angular velocity sensors (fiber optic gyroscopes). SwayStar was attached via a belt to the patient at the level L2/3 in the midline. The sensors were attached to a computer via a Bluetooth communication which sampled the velocity signals every $100 \mathrm{~ms}$ and numerically integrated the velocity signals to yield angular displacement. Trunk sway was measured as the total angle area (TAA) displacement (in degrees ${ }^{2}$ ) of the center of mass (level L2/3) during $8 \mathrm{~m}$ walk. This was calculated from total movement in the frontal and sagittal planes. The SwayStar has been used to assess trunk sway in many pathologies and differing age groups (Allum and Carpenter, 2005; Bischoff-Ferrari et al, 2006; Corporaal et al, 2013; Goutier et al, 2010; Horlings et al, 2009).

The measurement results are presented in Table 5 and plotted in Figures 6 and 7 to show changes over time during the different rehabilitation phases. "Celeration" or "Split Middle" lines, developed to quantify rate of change over time for single case reports or studies, have been plotted to show change in each rehabilitation phase.

\section{Muscle activity walking with and without assistive devices}

Muscle activity when walking without walking aids, with TheraTogs, and with crutches using electromyography (EMG) was measured. Measurements took place on different days. Walking without aids and with crutches were compared first, followed by walking without aids and with TheraTogs.

\section{Surface EMG measurements}

Surface EMG was used to measure muscle activity with a 16 bipolar channel Porti system (TMS International, Enschede, The Netherlands) of the gluteus maximus and gluteus medius using standard "European Recommendations for Surface Electromyography" (SENIAM) electrode placement (Hermens, Freriks, Disselhorst-Klug, and Rau, 2000) despite avulsion fracture, to investigate muscle activity at this level and possible compensation mechanisms, TFL, quadriceps, and hamstrings of the left (affected) leg when walking with and without aids. Gait cycles were defined as heel strike to heel strike of the same leg determined by a 
foot switch placed mid-heel and synchronized with the Porti system.

EMG activity during maximum voluntary contraction (MVC) for each muscle was collected on each occasion using the protocol described by Konrad (2006).

\section{EMG data collection}

Data were collected for each muscle over nine gait cycles as the patient walked at a self-selected, comfortable speed. Skin was prepared for surface EMG placement, first shaved over the relevant muscles and cleaned with alcohol. Noraxon bipolar $\mathrm{Ag} / \mathrm{AgCl}$ surface $\mathrm{EMG}$ electrode pairs with an electrode diameter of $10 \mathrm{~mm}$ and an inter-electrode spacing of $20 \mathrm{~mm}$ (Noraxon USC, Inc., Scottsdale, AZ) were placed onto the skin overlying these muscles following the SENIAM guidelines (Hermens, Freriks, Disselhorst-Klug, and Rau, 2000). The ground electrode was placed overlying the sacrum.

EMG was measured at a sampling rate of $2048 \mathrm{~Hz}$ without filtering, so that the signals were measured including direct current (DC). The digitized data were high-pass filtered with a fourth-order filter with a cutoff frequency of $10 \mathrm{~Hz}$. The EMG signals were full wave rectified and each dataset of one gait cycle was interpolated to 500 data points using the MATLAB software package (MathWorks@, Inc., 1994-2014, Natick, MA). The data were exported to Microsoft Excel ${ }^{\bullet}$ (version 14.1.0, 2011) for further analysis.

\section{EMG analysis}

Mean EMG muscle activity for each muscle in each gait cycle was measured and a maximum of mean values and the standard deviation over nine gait cycles were calculated. EMG activity during MVC for each muscle (re-measured during each measurement at the beginning and end of each phase) was then determined. Maximum of the mean EMG activity during walking as a percentage of MVC was calculated when walking without aids, with TheraTogs, and with crutches. Percentage changes between conditions were calculated. Measurement results are presented in Table 4 and Figure 4.

\section{Intervention}

\section{Crutch walking (weeks 1-4)}

The patient continued working in a sedentary job and was able to drive a car. Hydrotherapy was completed twice weekly for active left hip and leg strengthening and mobilizing exercises within pain limits. A home exercise program of strengthening and stretching exercises was also completed within pain limits daily. The patient also walked $500 \mathrm{~m}$ to $1 \mathrm{~km}$ each day and had a structured program to reduce crutch use. Initially two crutches were used for the whole $1 \mathrm{~km}$ distance. On the basis of the structured program, crutch use was reduced.

\section{Response to treatment}

After 2 weeks, the patient could walk $500 \mathrm{~m}$ (7-12 min) without crutches and with minimal pain. Pain medication remained unchanged. During this period, gait speed was increasing indicating functional improvement, but trunk sway was also increasing indicating reduced trunk stability and reduced hip muscle control (Table 5 and Figures 6 and 7). Trunk sway increases with increasing gait speed, but the levels of this patient were higher than normal values and continued to increase (Goutier et al, 2010).

For the next 2 weeks, treatment continued. Figures 6 and 7 show that gait speed continued to improve but that trunk sway was also increasing. During these 2 weeks, the distance the patient was able to walk without crutches improved slightly to approximately $700 \mathrm{~m}$. It was still not possible to climb stairs without pain. After 4 weeks, patient and therapist felt that progress had slowed and that a change in treatment approach was necessary.

It was hypothesized that the crutches, which have been shown to reduce hip muscle activity during walking (Sonntag et al, 2000), were having a negative impact on the recovery of hip muscle strength and therefore gait function and trunk sway. As crutches were used for long periods daily, the likelihood of this effect was increased.

Table 4. EMG activity when walking (1) without aids then with crutches; and (2) without aids then with TheraTogs, as a percentage of maximum voluntary contraction mean (SD).

\begin{tabular}{|c|c|c|c|c|c|}
\hline & \multicolumn{5}{|c|}{ EMG activity as a percentage of maximum voluntary contraction* } \\
\hline & Glut maximus & Glut medius & Tensor fascia lata & Quadriceps & Hamstrings \\
\hline Without assistive devices & $41.95(7.24)$ & $64.23(10.39)$ & $62.32(18.74)$ & $44.12(11.44)$ & $35.07(3.80)$ \\
\hline With crutches & $13.20(3.48)$ & $29.08(5.97)$ & $36.46(20.22)$ & $19.65(6.89)$ & $23.80(10.29)$ \\
\hline$\%$ Change & $-27.75(9.80)$ & $-35.14(12.59)$ & $-25.87(20.80)$ & $-24.47(6.73)$ & $-11.27(9.91)$ \\
\hline Without assistive devices & $58.19(69.19)$ & 45.73 (16.49) & $29.38(12.72)$ & $20.13(3.22)$ & $39.43(5.00)$ \\
\hline With TheraTogs & $59.87(66.74)$ & 60.85 (17.79) & $37.63(13.02)$ & $23.07(7.64)$ & $48.14(12.75)$ \\
\hline$\%$ Change & $+18.33(26.1)$ & +36.18 (25.19) & +31.41 (25.19) & $+14.16(22.06)$ & $+24.15(41.35)$ \\
\hline
\end{tabular}

*Measured on different days. Percentage change not absolute values compared. 
Table 5. Gait speed and trunk sway in each phase.

\begin{tabular}{|c|c|c|c|}
\hline Measures & \multicolumn{3}{|c|}{ Phases } \\
\hline $\begin{array}{l}\text { Gait speed }(\mathrm{m} / \mathrm{s}) \\
\text { Measurement point }\end{array}$ & $\begin{array}{c}\text { Phase A Crutch } \\
\text { walking }\end{array}$ & $\begin{array}{l}\text { Phase B } \\
\text { TheraTogs }\end{array}$ & $\begin{array}{l}\text { Phase C } \\
\text { No walking } \\
\text { aids }\end{array}$ \\
\hline 1 & 1.01 & 1.25 & 1.29 \\
\hline 2 & 1.01 & 1.19 & 1.51 \\
\hline 3 & 1.03 & 1.21 & 1.10 \\
\hline 4 & 1.23 & 1.43 & 1.14 \\
\hline 5 & 1.16 & 1.38 & 1.10 \\
\hline 6 & 1.16 & 1.48 & 1.05 \\
\hline 7 & 1.13 & 1.48 & 1.19 \\
\hline 8 & 1.16 & 1.38 & 1.14 \\
\hline Mean (SD) & $1.11(0.08)$ & $1.35(0.11)$ & $1.19(0.14)$ \\
\hline Median (IQR) & $1.14(0.14)$ & $1.38(0.25)$ & $1.14(0.17)$ \\
\hline \multicolumn{4}{|c|}{$\begin{array}{l}\text { Trunk sway-total angle } \\
\left.\text { area (degrees }{ }^{2}\right)\end{array}$} \\
\hline \multicolumn{4}{|c|}{ Measurement point } \\
\hline 1 & 59.04 & 71.96 & 100.49 \\
\hline 2 & 48.08 & 85.43 & 88.12 \\
\hline 3 & 49.04 & 61.36 & 85.63 \\
\hline 4 & 73.86 & 67.63 & 74.82 \\
\hline 5 & 59.10 & 68.38 & 101.70 \\
\hline 6 & 107.11 & 61.28 & 104.12 \\
\hline 7 & 89.90 & 81.74 & 87.11 \\
\hline 8 & 67.95 & 78.30 & 53.26 \\
\hline Mean (SD) & $69.26(20.51)$ & $72.01(9.06)$ & $86.90(16.82)$ \\
\hline Median (IQR) & $63.52(34.35)$ & $70.17(17.96)$ & $87.61(23.88)$ \\
\hline
\end{tabular}

Note. SD, standard deviation; IQR, interquartile range.

We considered that a walking aid which would increase hip abductor and extensor muscle activity while providing external hip support may be more appropriate. It was decided that the orthotic garment and strapping system TheraTogs applied to facilitate hip abductor and extensor muscle activity would be an appropriate treatment alternative to crutch walking. It was not clear at this point whether the hip joint which would now be loaded (partial weight-bearing would no longer be possible as arms are not used with TheraTogs) would become more painful.

\section{TheraTogs (weeks 5-8)}

TheraTogs consists of an inner "suit" worn next to the patient's skin under the clothes. The outer surface is
Velcro-sensitive allowing the attachment of elasticated straps. The straps provide a gentle pressure with the aim of improving joint alignment and increasing muscle activity. The orthosis was individually adapted and applied to facilitate hip abductor and extensor muscle activity (Figure 3). The patient applied TheraTogs in the morning when dressing and wore it throughout the day until undressing at night. During this period crutches were not used.

The patient continued with strengthening and stretching exercises twice weekly in water and daily home exercises.

\section{Response to treatment}

The patient continued initially to walk $500 \mathrm{~m}$ without crutches but now wearing TheraTogs and pain was absent or minimal. After 2-3 weeks, this increased to $1 \mathrm{~km}$ taking $15-20 \mathrm{~min}$. The patient was full weightbearing, but still wearing TheraTogs. Pain medication remained unchanged. After 4 weeks, the patient could walk approximately $1.5 \mathrm{~km}$ with TheraTogs and distance without aids remained approximately $700 \mathrm{~m}$.

Gait speed continued to improve and at a faster rate than during the crutch walking phase (Table 5 and Figure 6). Trunk sway was reduced compared with the earlier phase although gait speed was increasing. Stair climbing was possible when wearing TheraTogs and using a bannister. It remained painful however and the patient reported that TheraTogs acted more as a hindrance than a help. This may have been because the strap applied to facilitate hip muscle extensor activity opposed hip flexion.

After 2 weeks, the patient was able to commence cycling with an e-bike and began a twice weekly ride of 5-10 km. Sometimes this would replace the hydrotherapy session. TheraTogs was uncomfortable when cycling. At the end of 4 weeks, gait speed had

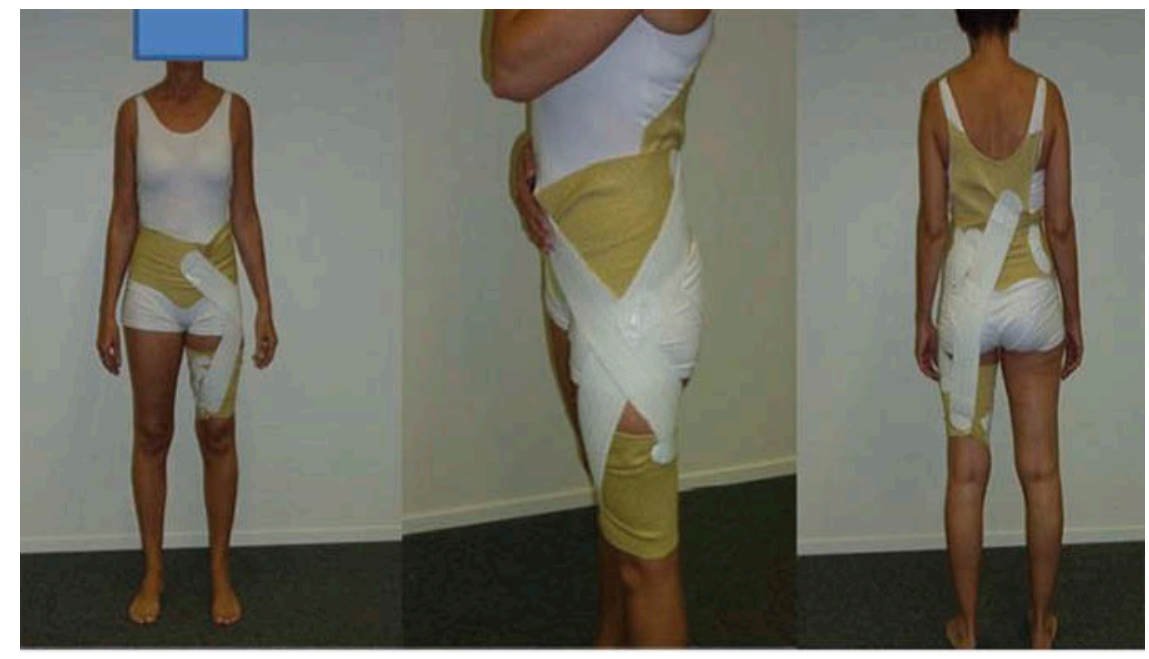

Figure 3. TheraTogs adapted for easy application by the patient herself and applied to facilitate hip abductor and extensor activity. 
significantly improved and trunk sway had become more stable. The patient was able to walk longer distances without pain and stair climbing although still a bit uncomfortably. The patient felt that TheraTogs provided stability and support when walking, but was a hindrance when stair climbing and uncomfortable when sitting or cycling. Additionally, the patient felt restricted in the clothes she could wear with TheraTogs and was often warm on hot days. As gait speed and trunk sway had improved and pain was controlled, the patient and therapist decided to progress treatment and attempt to remove walking aids from daily activities and walking.

The question as to whether pelvic stability was improved through improved pelvic muscle activity or through passive support of the orthosis itself remained unclear. Muscle activity when walking without walking aids, with TheraTogs, and with crutches using EMG was measured as mentioned earlier to help clarify this question.

\section{EMG - the immediate effects on muscle activity}

As shown in Table 4, muscle activity was reduced in all muscle groups when walking with crutches and increased in all muscle groups when walking with TheraTogs. Figure 4 shows typical examples of these effects for the measurements over the standard SENIAM hip abductor position. The nature of EMG means that absolute values on different days cannot be compared. The percentage change between conditions can however be compared (Konrad, 2006).

\section{No walking aids (weeks 9-12)}

The patient now began to walk throughout the day without walking aids. Gait speed and trunk sway continued to be measured twice weekly. Initially strengthening and stretching exercises in water and at home were continued. Cycling with an e-bike 5-10 $\mathrm{km}$ once or twice a week and the daily walk was also continued.

\section{Response to treatment}

After 2 days, pain began to increase when walking. After 7-10 days, pain had increased significantly and began to limit function. An acute inflammation at the anatomical level of the greater trochanter was diagnosed as the exposed prosthesis irritated soft tissues. Non-steroidal anti-inflammatory Eterocoxib $(90 \mathrm{mg})$ to be taken once in the evening and rest were prescribed. Due to the pain the patient discontinued the e-bike riding and daily walks. Because of high levels of inactivity and the increased pain, gait speed reduced and trunk sway increased substantially (Figures 6 and 7). The patient continued to rest as prescribed for the following 10-14 days.
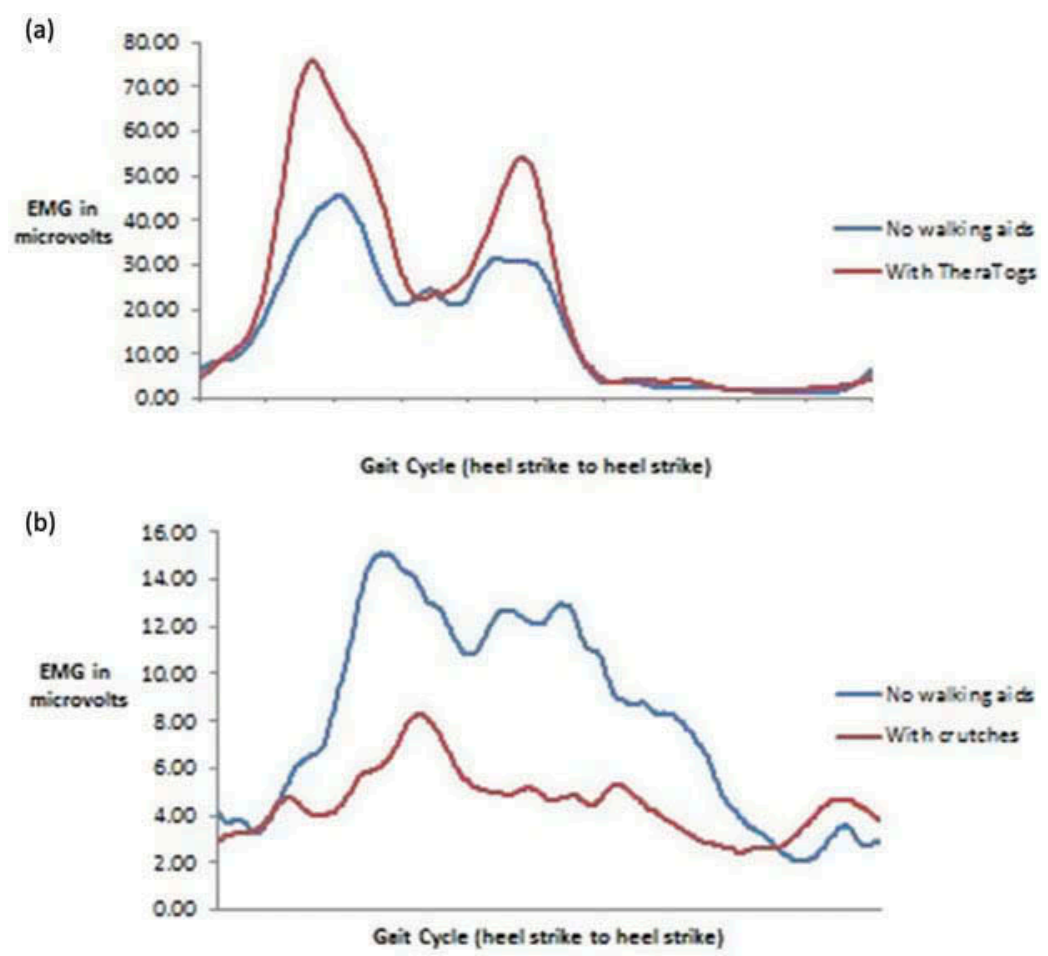

Figure 4. Mean EMG activity over nine gait cycles at the gluteus medius electrode placement position walking comparing (a) walking without aids with TheraTogs; and (b) walking without aids with crutches. 


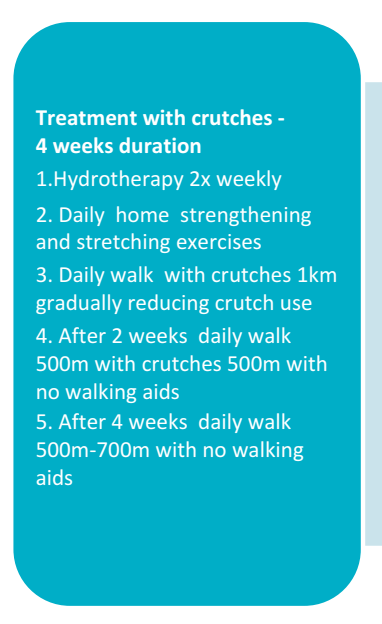

Treatment with TheraTogs 4 weeks duration

1. Hydrotherapy $2 x$ weekly

2. Daily home strengthening and

stretching exercises

3. Daily walk $500 \mathrm{~m}-700 \mathrm{~m}$ with

TheraTogs. Approx. $1 \mathrm{x}$ weekly

with no walking aids

4. After 2-3 weeks daily walk $1 \mathrm{~km}$

with TheraTogs. Approx. $1 \mathrm{x}$

weekly $500 \mathrm{~m}-700 \mathrm{~m}$ with no

walking aids

5. After 4 weeks daily walk $1.5 \mathrm{~km}$

with TheraTogs. Maximum

distance without aids (1x weekly)

remained $700 \mathrm{~m}$.

6. After 2 weeks commenced e-

bike riding of $5-10 \mathrm{~km}$ sometimes

replacing hydrotherapy.

Figure 5. Timeline of treatment interventions.

At this point (12 weeks following the commencement of gait rehabilitation), it seemed unlikely that treatment aims of returning to prefracture levels of mobility without walking aids would be achieved. Treatment aims of increasing hip muscle strength and mobility to enable walking without aids were not achieved. The patient's goals of being able to complete work and leisure tasks without walking aids were also not achieved. The patient was reluctant to return to either crutch walking or TheraTogs on a long-term basis. Both of these walking aids had improved functional mobility while they were being used but the patient's goal was to walk without assistive devices. It appeared that supporting the hip joint either through partial weight-bearing with crutches

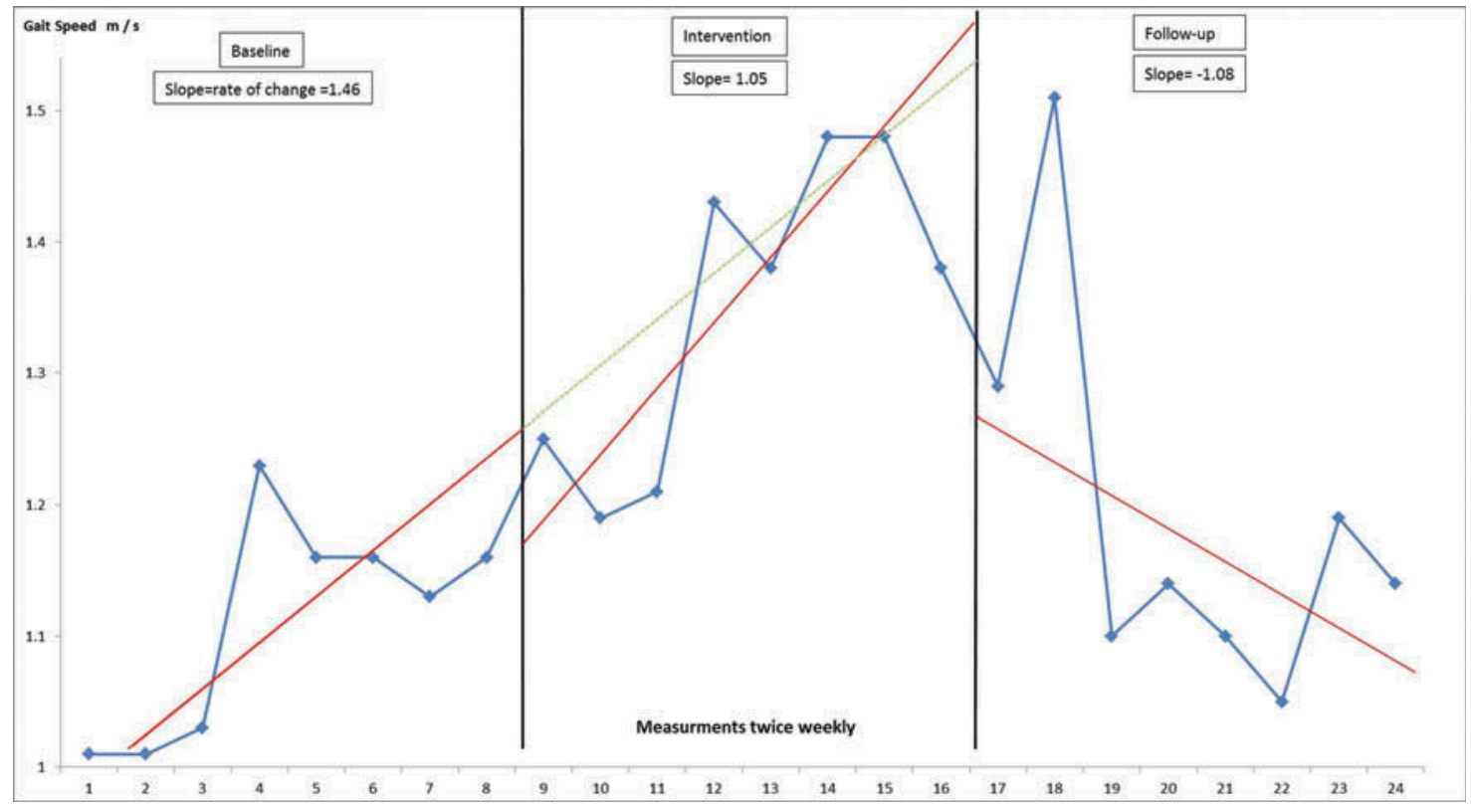

Figure 6. Gait speed-twice weekly measurements during gait rehabilitation with crutches, TheraTogs, and without walking aids. Red line is the calculated "Celeration" line indicating rate of change in each phase. The green line in the TheraTogs phase indicates expected values in TheraTogs phase if rate of change from crutch walking had continued. 


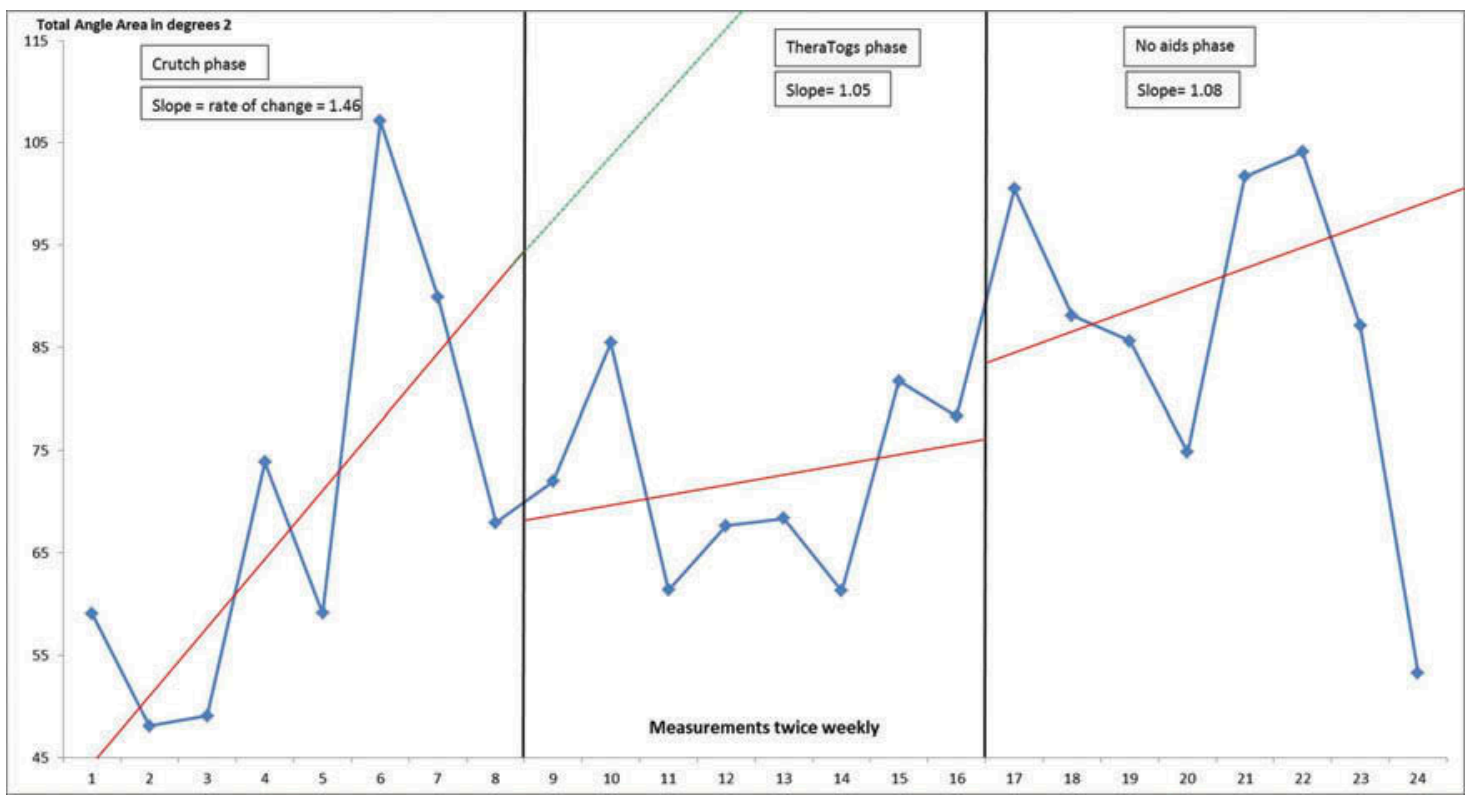

Figure 7. Trunk sway-twice weekly measurements during gait rehabilitation with crutches, TheraTogs, and without walking aids. Increasing values indicate greater instability. Red line is the calculated "Celeration" line indicating rate of change in each phase. The green line in the TheraTogs phase indicates expected values in TheraTogs phase if rate of change from crutch walking had continued.

or through facilitation of muscle activity and the passive support from TheraTogs was necessary to reduce inflammation and pain when walking. A timeline overview of treatment interventions is presented in Figure 5.

\section{Outcome}

\section{Surgical intervention}

Imaging showed that the trochanter fracture had formed a pseudarthrosis. The shoulder of the hip prosthesis continued to irritate overlying soft tissues and the abductor mechanism, attached to the displaced trochanter fragment, could not be normally retrained. Surgery was carried out to change the shaft of the prosthesis, repair the pseudarthrosis with autologous bone grafting, and reattachment of the fragment of the trochanter to the femur with osteosynthesis. Thus, the gluteal musculature was also reattached. At the time of this report, the patient was non-weight-bearing. It was expected to take 4-6 months before the procedure was completed and the patient could begin to fully weight bear.

\section{Discussion}

\section{Effects of the walking aids during rehabilitation}

To our knowledge, this is the first detailed case to document the specific influence of walking aids over a prolonged period on functional recovery in orthopedic rehabilitation.

\section{Gait speed and trunk sway}

Table 5 and Figures 6 and 7 show the changes in gait speed and trunk sway as the patient underwent gait rehabilitation using different walking aids. Gait speed increased during crutch walking. It continued to improve with TheraTogs at a faster rate of change (steeper slope) and reduced when walking with no aids. Gait speed $(\mathrm{m} / \mathrm{s})$ mean $(\mathrm{SD})$ changed from $1.11(0.08)$ in crutch phase to $1.35(0.11)$ with TheraTogs. According to Alley et al (2011) who investigated meaningful improvement in gait speed in 217 women following hip fracture, this represents a "substantial functional improvement." This was mirrored in the activity levels when walking with TheraTogs. A daily walk of $500 \mathrm{~m}$ to $1 \mathrm{~km}$ was continued as during crutch walking, but the patient was fully weight-bearing. One to two weekly bike rides of $5-10 \mathrm{~km}$ were also done on a regular basis. During the no-walking-aids phase, gait speed reduced again to $1.19(0.14) \mathrm{m} / \mathrm{s}$. The patient's function was substantially reduced, shown by the necessity to stop activity such as daily walks and e-bike riding.

Trunk sway increased steadily indicating increasing pelvic and balance instability during the crutch walking phase. In healthy subjects, increasing gait speed is associated with increased trunk sway (Goutier et al, 2010). It could be argued therefore that the increased values 
were due to increasing gait speed as values remained well above normal. Normal values for the average gait speed obtained by this patient when walking with crutches vary between 18.0 and 31.6 degrees $^{2}$ (Goutier et al, 2010). This value in our patient was 69.3 (20.5) degrees $^{2}$ indicating instability and consistent with the generalized weakness around the hip. Increasing trunk sway is associated with an increased risk of falling (Bischoff-Ferrari et al, 2006; Dingwell and Marin, 2006; Goutier et al, 2010; van Iersel et al, 2007).

During the TheraTogs phase the values became less variable, exhibiting fewer extremes of movement and indicating improved stability. The rate of increase was much reduced compared with crutch walking, even though gait speed increased. In the no-walking-aids phase, trunk sway again began to increase at a faster rate indicating greater instability despite reducing gait speed.

\section{Muscle activity}

When walking with crutches, muscle activity was reduced in all muscle groups compared with walking with no aids, confirming the findings of Sonntag et al (2000). Despite this, gait speed increased. A possible explanation is that the unloading which occurs at the hip joint when walking with crutches (Bateni and Maki, 2005) not only caused an ongoing reduction in muscle activity but also enabled spontaneous recovery of the affected structures resulting in increased gait speed. However, given the importance of hip abductor control in postural stability (Gribble and Hertel, 2004; Negahban et al, 2013), the constant inhibition of this activity in this phase may have been responsible for the increasing trunk sway.

The immediate effect of TheraTogs on muscle activity compared with walking without aids was an increased activity in all muscle groups with the largest effects at the hip abductor muscles (gluteus medius) and hamstrings. The mechanism by which TheraTogs facilitates muscle activity has not been determined. It may be that propriceptive input from the elasticated straps facilitates muscle activity or that the passive correction of biomechanical alignment during walking "normalizes" muscle length allowing improved contraction. Due to the avulsion fracture of the greater trochanter, the biomechanical source of the abductor activity remained unclear but the functional relevance was demonstrated through improved walking speed and trunk sway. The activity could have been the result of surface EMG crosstalk (EMG signal generated by a nearby muscle) (Beck, DeFreitas, and Stock, 2010; Farina, Merletti, Indino, and Graven-Nielsen, 2004), for example, from TFL, or it may have arisen from muscular contractile elements which can fuse with the gluteal aponeurosis (Netter, 2014).

\section{Possible implications for clinical practice}

Walking with TheraTogs increased muscle activity, gait speed improved at a faster rate than crutch walking although the hip was not unloaded through partial weight-bearing, and trunk stability improved. The facilitation of muscle activity through TheraTogs may have accounted for increasing gait speed in this phase and stabilization of trunk sway due to increased activity in hip abductors.

However, the gains made during the TheraTogs phase were not maintained when walking without aids. The influence of the exposed prosthesis may have prevented long-term benefits. When walking without aids gait speed and trunk stability deteriorated, possibly because the hip was not supported either through unloading or due to facilitation of muscle activity. The exposed shoulder of the prosthesis caused increased irritation and inflammation of overlying soft tissues during walking. This could explain the increased pain, reduction in trunk stability (pain inhibition of muscle activity), and reduction of gait speed. All outcome measures deteriorated when walking with no aids and daily activity was reduced. Improvements in strength and function made during treatment with TheraTogs were insufficient to ensure independent support of the joint with no aids. These changes could not prevent irritation of overlying soft tissues and the escalation of inflammation and pain.

Ultimately the patient's goal of walking independently without aids was not achieved through conservative interventions. As the patient was reluctant to use walking aids long-term, surgery was considered necessary to restore function.

Overall the results measured with this patient suggest that TheraTogs may offer an attractive alternative to crutch walking in orthopedic patients particularly if assistance is needed in the progression to full weightbearing. TheraTogs appeared to provide adequate support to the recovering structures while facilitating muscle activity. This enabled an increased recovery rate of all measured parameters compared with walking with crutches. In this patient, these changes were not maintained when progressing to walking with no aids. However, the exposed prosthesis irritating overlying structures caused a more challenging situation than in many patients following orthopedic hip surgery. 
As up to $20 \%$ of patients demonstrate a failure of the hip abductor mechanism following THR (Odak and Ivory, 2013), and as post-operative fracture of the greater trochanter is not uncommon (Pritchett, 2001), this functional improvement may be particularly important for this patient group who are often treated conservatively (Odak and Ivory, 2013).

As hand-held assistive devices have been shown to be associated with increased risk of falling, possibly due to tripping or by diverting attentional resources (Bateni and Maki, 2005), devices such as TheraTogs may avoid these drawbacks. Problems due to repetitive stress on upper extremity joints are also avoided.

It is important to emphasize that these results have only been confirmed in one patient and cannot be generalized. Research to investigate the long-term impact of different walking aids on the functional recovery of gait and balance are needed.

\section{Acknowledgment}

The authors thank Hans-Peter Karrer from the Bildungszentrum Gesundheit Basel-Stadt for his support.

\section{Declaration of interest}

The authors report no declarations of interest.

\section{References}

Abd El-Kafy EM 2014 The clinical impact of orthotic correction of lower limb rotational deformities in children with cerebral palsy: A randomized controlled trial. Clinical Rehabilitation 28: 1004-1014.

Alley DE, Hicks GE, Shardell M, Hawkes W, Miller R, Craik RL, Mangione KK, Orwig D, Hochberg M, Resnick B, Magaziner J 2011 Meaningful improvement in gait speed in hip fracture recovery. Journal of the American Geriatric Society 59: 1650-1657.

Allum JH, Carpenter MG 2005 A speedy solution for balance and gait analysis: Angular velocity measured at the centre of body mass. Current Opinion in Neurology 18: 15-21.

Archdeacon M, Ford KR, Wyrick J, Paterno MV, Hampton S, Ludwig MB, Hewett TE 2008 A prospective functional outcome and motion analysis evaluation of the hip abductors after femur fracture and antegrade nailing. Journal of Orthopaedic Trauma 22: 3-9.

Bateni H, Maki BE 2005 Assistive devices for balance and mobility: Benefits, demands, and adverse consequences. Archives of Physical Medicine and Rehabilitation 86: 134-145.

Beck TW, DeFreitas JM, Stock MS 2010 Cross-talk among monopolar surface electromyographic signals from the superficial quadriceps femoris muscles. Electromyography and Clinical Neurophysiology 50: 245-250.
Bischoff-Ferrari HA, Conzelmann M, Stähelin HB, Dick W, Carpenter MG, Adkin AL, Theiler R, Pfeifer M, Allum JH 2006 Is fall prevention by vitamin $\mathrm{D}$ mediated by a change in postural or dynamic balance? Osteoporos International 17: 656-663.

Borrelli J, Ricci WM, Anglen JO, Gregush R, Engsberg J 2006 Muscle strength recovery and its effects on outcome after open reduction and internal fixation of acetabular fractures. Journal of Orthopaedic Trauma 20: 388-395.

Corporaal SH, Gensicke H, Kuhle J, Kappos L, Allum JH, Yaldizli Ö 2013 Balance control in multiple sclerosis: Correlations of trunk sway during atance and gait tests with disease severity. Gait and Posture 37: 55-60.

Dingwell JB, Marin LC 2006 Kinematic variability and local dynamic stability of upper body motions when walking at different speeds. Journal of Biomechics 39: 444-452.

Farina D, Merletti R, Indino B, Graven-Nielsen T 2004 Surface EMG crosstalk evaluated from experimental recordings and simulated signals. reflections on crosstalk interpretation, quantification and reduction. Methods of Information in Medicine 43: 30-35.

Garcia FL, Picado CH, Nogueira-Barbosa MH 2010 Sonographic evaluation of the abductor mechanism after total hip arthroplasty. Journal of Ultrasound in Medicine 29: 465-471.

Goutier KM, Jansen SL, Horlings CG, Küng UM, Allum JH 2010 The influence of walking speed and gender on trunk sway for the healthy young and older adults. Age and Ageing 39: 647-650.

Gribble PA, Hertel J 2004 Effect of hip and ankle muscle fatigue on unipedal postural control. Journal of Electromyography and Kinesiology 14: 641-646.

Hermens HJ, Freriks B, Disselhorst-Klug C, Rau G 2000 Development of recommendations for SEMG sensors and sensor placement procedures. Journal of Electromyography and Kinesiology 10: 361-374.

Hol AM, van Grinsven S, Lucas C, van Susante JL, van Loon CJ 2010 Partial versus unrestricted weight bearing after an uncemented femoral stem in total hip arthroplasty: Recommendation of a concise rehabilitation protocol from a systematic review of the literature. Archives of Orthopaedic and Trauma Surgery 130: 547-555.

Horlings CG, Küng UM, van Engelen BG, Voermans NC, Hengstman GJ, van der Kooi AJ, Bloem BR, Allum JH 2009 Balance control in patients with distal versus proximal muscle weakness. Neuroscience 164: 1876-1886.

Howell GE, Biggs RE, Bourne RB 2001 Prevalence of abductor mechanism tears of the hips in patients with osteoarthritis. Journal of Arthroplasty 16: 121-123.

Hung WW, Egol KA, Zuckerman JD, Siu AL 2012 Hip fracture management: Tailoring care for the older patient. JAMA 307: 2185-2194.

Klemetti R, Steele KM, Moilanen P, Avela J, Timonen J 2014 Contributions of individual muscles to the sagittal- and frontal-plane angular accelerations of the trunk in walking. Journal of Biomechics 47: 2263-2268.

Konrad P 2005 The ABC of EMG-a practical introduction to kinesiological electromyography. Scottsdale, AZ, Noraxon Inc.

Maguire C, Sieben JM, Frank M, Romkes J 2010 Hip abductor control in walking following stroke - the immediate effect of canes, taping and theratogs on gait. Clinical Rehabilitation 24: 37-45. 
Masonis JL, Bourne RB 2002 Surgical approach, abductor function and total hip arthroplasty dislocation. Clinical Orthopaedics and Related Research 405: 46-53.

Negahban H, Etemadi M, Naghibi S, Emrani A, Shaterzadeh Yazdi MJ, Salehi R, Moradi Bousari A 2013 The effects of muscle fatigue on dynamic standing balance in people with and without patellofemoral pain syndrome. Gait and Posture 37: 336-339.

Netter FH 2014 Atlas of human anatomy, 6th edn. Philadelphia, Elsevier Saunder.

Neumann DA 1998 Hip abductor muscle activity as subjects with hip prostheses walk with different methods of using a cane. Physical Therapy 78: 490-501.

Odak S, Ivory J 2013 Management of abductor mechanism deficiency following total hip replacement. Bone and Joint Journal 95-B: 343-347.

Piva SR, Teixeira PE, Almeida GJ, Gil AB, DiGioia AM, Levison TJ, Fitzgerald GK 2011 Contribution of hip abductor strength to physical function in patients with total knee arthroplasty. Physical Therapy 91: 225-233.

Pritchett JW 2001 Fracture of the greater trochanter after hip replacement. Clinical Orthopaedics and Related Research 390: 221-226.

Richards A, Morcos S, Rethlefsen S, Ryan D 2012 The use of theratogs versus twister cables in the treatment of in-toeing during gait in a child with spina bifida. Pediatric Physical Therapy 24: 321-326.
Robbins CE, Casey D, Bono JV, Murphy SB, Talmo CT, Ward DM 2014 A multidisciplinary total hip arthroplasty protocol with accelerated postoperative rehabilitation: Does the patient benefit? American Journal of Orthopedics 43: 178-181.

Sonntag D, Uhlenbrock D, Bardeleben A, Kading M, Hesse S 2000 Gait with and without forearm crutches in patients with total hip arthroplasty. International Journal of Rehabilitation Research 23: 233-243.

Tayrose G, Newman D, Slover J, Jaffe F, Hunter T, Bosco Iii J 2013 Rapid mobilization decreases length-of-stay in joint replacement patients. Bulletin of the Hospital for Joint Disease 71: 222-226.

van Iersel MB, Ribbers $H$, Munneke $M$, Borm GF, Rikkert MG 2007 The effect of cognitive dual tasks on balance during walking in physically fit elderly people. Archives of Physical Medicine and Rehabilitation 88: 187-191.

Westerman RW, Hull P, Hendry RG, Cooper J 2008 The physiological cost of restricted weight bearing. Injury 39: 725-727.

Williams BS, Cohen SP 2009 Greater trochanteric pain syndrome: A review of anatomy, diagnosis and treatment. Anesthesia and Analgesia 108: 1662-1670.

Zhao Y, Chen SY, Lee YC, Wu N 2013 Clinical and economic characteristics of hip fracture patients with and without muscle atrophy/weakness in the United States. Archives of Osteoporosis 8: 127. 